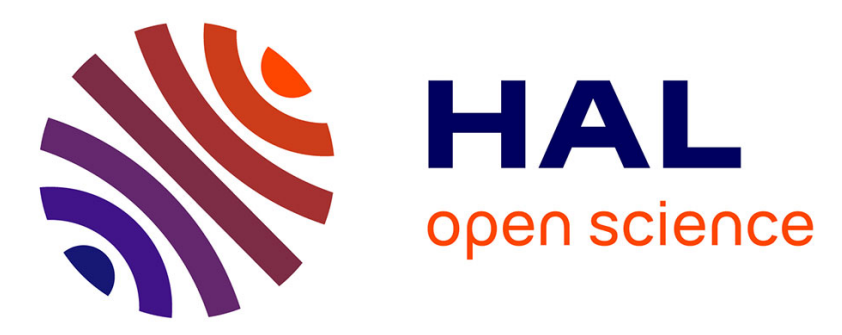

\title{
Upward migration of Vesuvius magma chamber over the past 20 thousand years
}

Bruno Scaillet, Michel Pichavant, R. Cioni

\section{To cite this version:}

Bruno Scaillet, Michel Pichavant, R. Cioni. Upward migration of Vesuvius magma chamber over the past 20 thousand years. Nature, 2008, 455 (11 septembre), pp.216-219. 10.1038/nature07232 . insu-00310129

\section{HAL Id: insu-00310129 \\ https://hal-insu.archives-ouvertes.fr/insu-00310129}

Submitted on 31 Oct 2009

HAL is a multi-disciplinary open access archive for the deposit and dissemination of scientific research documents, whether they are published or not. The documents may come from teaching and research institutions in France or abroad, or from public or private research centers.
L'archive ouverte pluridisciplinaire HAL, est destinée au dépôt et à la diffusion de documents scientifiques de niveau recherche, publiés ou non, émanant des établissements d'enseignement et de recherche français ou étrangers, des laboratoires publics ou privés. 


\title{
Upward migration of Vesuvius magma chamber over the past 20,000 years
}

\author{
B. Scaillet ${ }^{1,2}$, M. Pichavant ${ }^{1,2} \&$ R. Cioni ${ }^{3,4}$
}

1. CNRS/INSU—Institut des Sciences de la Terre d'Orléans, 1a rue de la Férollerie, 45071 Orléans, cedex 2, France

2. Université d'Orléans - Institut des Sciences de la Terre d'Orléans, 45071 Orléans, France

3. Dipartimento di Scienze della Terra, Via Trentino 51, 09127 Cagliari, Italy

4. INGV, sezione di Pisa, Via della Faggiola, 56100 Pisa, Italy

Forecasting future eruptions of Vesuvius is an important challenge for volcanologists, as its reawakening could threaten the lives of 700,000 people living near the volcano ${ }^{1,2}$. Critical to the evaluation of hazards associated with the next eruption is the estimation of the depth of the magma reservoir, one of the main parameters controlling magma properties and eruptive style. Petrological studies have indicated that during past activity, magma chambers were at depths between 3 and $16 \mathrm{~km}$ (refs 3-7). Geophysical surveys have imaged some levels of seismic attenuation, the shallowest of which lies at 8-9 km depth ${ }^{8}$, and these have been tentatively interpreted as levels of preferential magma accumulation. By using experimental phase equilibria, carried out on material from four main explosive events at Vesuvius, we show here that the reservoirs that fed the eruptive activity migrated from $7-8 \mathrm{~km}$ to $3-4 \mathrm{~km}$ depth between the AD 79 (Pompeii) and AD 472 (Pollena) events. If data from the Pomici di Base event $18.5 \mathrm{kyr}$ ago $^{9}$ and the 1944 Vesuvius eruption $^{7}$ are included, the total upward migration of the reservoir amounts to 9-11 km. The change of preferential magma ponding levels in the upper crust can be attributed to differences in the volatile content and buoyancy of ascending magmas, as well as to changes in local stress field following either caldera formation ${ }^{10}$ or volcano spreading ${ }^{11}$. Reservoir migration, and the possible influence on feeding rates ${ }^{12}$, should be integrated into the parameters used for defining expected eruptive scenarios at Vesuvius.

The comparison of natural and experimental phase assemblages obtained from hydrothermal experiments represents a powerful approach to assess pre-eruption conditions, in particular pressure, in subvolcanic magma reservoirs, as shown for the eruptions of Mount St Helens ${ }^{13}$, Mount Pelée ${ }^{14}$ and Mount Pinatubo ${ }^{15}$, among others. To this end, we investigated the phase equilibria of phonolite magma from four main explosive events of Vesuvius: Mercato (7800 BP), Avellino (3600 BP), Pompeii (79 AD) and Pollena (472 AD). Rocks selected for the experiments are representative of the first material erupted during each Plinian event (see Supplementary Information). This magma has been interpreted ${ }^{16,17,18,19,20}$ as being derived from the apical part of the reservoir, being the most evolved of the erupted products. Although magma mixing affects most of the products erupted during large eruptions ${ }^{16,17,18,19}$, petrological and geochemical studies suggest that the first phonolites to be erupted did not experience this process. The compositional and mineralogical differences of the four studied phonolites can be interpreted in terms of different conditions of magma evolution and crystallization. In particular, isotopic analyses show that in the studied phonolites, phenocrysts and matrix glass share the same ${ }^{87} \mathrm{Sr} /{ }^{86} \mathrm{Sr}$ composition ${ }^{17,19}$, suggesting that the phonolitic cap of the reservoir approached crystal-liquid equilibrium before eruption. 
We used established laboratory procedures to carry out crystallization experiments (see Methods) to work out the phase relationships of the four phonolites over the pressure and temperature ranges $100-300 \mathrm{MPa}$ and $750-900^{\circ} \mathrm{C}$, and with varying fluid composition. Based on 216 experiments, both isobaric/polythermal and isothermal/polybaric sections were drawn. The isobaric/isothermal sections of Pompeii and Pollena phonolites are shown in Fig. 1. The full set of experimental data for each eruption can be found in the Supplementary Information. Phase relationships suggest similar equilibration pressures $(P \approx 200 \mathrm{MPa})$ for the three older phonolites (Mercato, Avellino, Pompeii). This is in general agreement with data from melt inclusions ${ }^{17}$ and geochemical studies ${ }^{21}$, which suggest a process of recycling of magma residuals in the same reservoir for the three eruptions. Conversely, our experiments document an important difference in pre-eruption pressure between the Pompeii and Pollena events.

Inspection of Fig. 1 shows that the phenocryst assemblage of Pompeii phonolite, consisting of sanidine, amphibole, garnet, clinopyroxene, leucite (rare), and plagioclase, can be reproduced at $200 \mathrm{MPa}$ under a restricted range of conditions of temperature and dissolved water content in the melt $\left(\mathrm{H}_{2} \mathrm{O}_{\text {melt }}\right)$, broadly centred at $815 \pm 10^{\circ} \mathrm{C}$ and $6 \mathrm{wt} \%$ dissolved $\mathrm{H}_{2} \mathrm{O}$. The polybaric phase relations established at $800{ }^{\circ} \mathrm{C}$ (see Supplementary Information) show in contrast that pressures significantly lower than $200 \mathrm{MPa}$ do not reproduce the observed phase assemblage, in particular because amphibole is no longer stable near the liquidus. Altogether, a pressure of $200 \pm 20 \mathrm{MPa}$ is taken as the condition prevailing in the upper part of the zoned reservoir tapped by the Pompeii eruption. Phase equilibrium considerations for Mercato and Avellino phonolites lead to a similar estimate for the pressure of magma storage (Table 1, see Supplementary Information). In contrast, at $200 \mathrm{MPa}$ the phenocryst assemblage of Pollena phonolite cannot be reproduced experimentally. Clinopyroxene would be largely present at subliquidus conditions at $200 \mathrm{MPa}$, but clinopyroxene and nepheline cannot co-precipitate at near-liquidus conditions, as demanded by the phenocryst assemblage and the crystal-poor character of Pollena pumice. The only way to crystallize nepheline and clinopyroxene together near the liquidus is to decrease pressure down to $100 \mathrm{MPa}$ in the experiments (Fig. 1b). This decrease in pressure promotes leucite growth at the expense of sanidine, in agreement with the petrographic features of Pollena pumice, which shows rare sanidine and abundant leucite (Supplementary Information, and ref. 20), whereas the reverse is observed in Pompeii phonolite. As a general fact, leucite is nearly absent in pre-Pompeii magmas, but abundant in post-Pompeii deposits ${ }^{22}$.

Additional evidence for such a difference in pressure between the Pompeii and Pollena reservoirs comes from the study of volatiles trapped in melt inclusions ${ }^{6,23}$. Pompeii pumice is characterized by pre-eruptive dissolved water contents of 6-7 wt\% (ref. 23), in good agreement with the range predicted from phase equilibrium considerations (Fig. 1). In contrast, the water content of melt inclusions in Pollena phonolite phenocrysts (3-5 wt\%; ref. 6) indicates trapping pressures around $100 \mathrm{MPa}$ (ref. 6). We conclude that the level of preferential magma accumulation migrated upward between the Pompeii and Pollena events. Considering an average crustal density of $2,600 \mathrm{~kg} \mathrm{~m}^{-3}$, such a difference of $100 \mathrm{MPa}$ would correspond to a depth difference of about $4 \mathrm{~km}$.

Pre-eruption conditions are less well constrained for events either older than the Mercato or younger than the Pollena eruptions, although they can be obtained from field and petrological data. The Pomici di Base eruption, the first Plinian event at Somma-Vesuvius, dated around $18.5 \mathrm{kyr}$ ago $^{9}$, ejected trachytic to latitic magmas. A thermobarometric approach using feldspar phenocrysts from this eruption ${ }^{9}$ has yielded equilibrium pressure in the range 300 $500 \mathrm{MPa}$. Although these estimates are associated with a significant uncertainty, they clearly 
point towards pressure of magma storage equivalent to, or even higher than, that of younger Plinian events. Since the sub-Plinian Pollena event, a number of eruptions have occurred, including the 1631 event, which has considerable similarities in eruption style, magma composition and mineral assemblage to the Pollena event ${ }^{24,25}$. As in the Pollena rocks, the widespread occurrence of leucite phenocrysts in the 1631 tephra strongly suggests that low pressure conditions prevailed during pre-eruptive magma storage, possibly at around $100 \mathrm{MPa}$. Following the 1631 eruption, the activity of Vesuvius shifted towards a semipersistent state, which continued up to the last event in 1944. This period was characterized by a Strombolian-type dynamism with alternating explosive and effusive phases ${ }^{26,27}$, with intervening repose times not longer than $7 \mathrm{yr}$ and violent Strombolian eruptions as the most intense events ${ }^{26,27}$. In two of the largest eruptions of this period, in 1906 and 1944, 7, 26, melt inclusions in olivine and diopside testify to the arrival of deep mafic magma batches (pressures >300 MPa; refs 5,7) before the eruption. Salitic clinopyroxene and leucite phenocrysts host melt inclusions with $\mathrm{H}_{2} \mathrm{O}$ contents hardly exceeding $1 \mathrm{wt} \%$ and no $\mathrm{CO}_{2}$, yielding entrapment pressures in the range 50-80 MPa (ref. 7) which suggest that crystallization occurred in a reservoir no deeper than $3 \mathrm{~km}$.

Figure 2a plots the pressure of magma storage and crystallization for selected Vesuvius eruptions (Table 1) against eruption age. Clearly, there is a decrease in pressure from $300 \pm$ $100 \mathrm{MPa}$ at $18.5 \mathrm{kyr}$ ago, down to less than $100 \mathrm{MPa}$ for the 1906-44 events. Thus, our study highlights the existence of various, yet not synchronous, shallow reservoirs beneath Vesuvius in which chemical differentiation occurred. Petrological and geochemical arguments show that these shallow reservoirs grew over time by repeated injection of mafic batches ${ }^{17,18,19}$ coming from a deeper reservoir or directly from the source region ${ }^{5,6,7}$. In addition to this agedepth correlation, the available data show that there is a close relationship between extent of magma differentiation, repose time and depth of the reservoir (Fig. 2b). Reservoirs of Plinian eruptions, all located at pressures of at least $200 \mathrm{MPa}$, invariably produced trachyte to phonolite magmas with MgO contents lower than $0.5 \mathrm{wt} \%$ (Table 1) and erupted after a period of quiescence ranging from hundreds to thousands of years ${ }^{18,22}$. The shallower reservoirs, which characterized the recent Pollena and 1631 events, fractionated up to tephriphonolitic compositions, being able to produce only small volumes of phonolite (MgO between 0.7 and $1.7 \mathrm{wt} \%$ ) (Table 1). In both cases, the production of felsic derivatives testifies to the possibility of significant magma cooling and differentiation during upper crustal residence. In contrast, the magma erupted during the 1944 and 1906 eruptions is a potassium-rich tephrite to phonotephrite with $\mathrm{MgO}$ contents always higher than $2.5 \mathrm{wt} \%$ (Table 1). Inversion of diffusion profiles in 1944 clinopyroxenes shows that residence of deep phenocrysts within the shallow reservoir was $9 \mathrm{yr}$ or less ${ }^{28}$. Altogether, this suggests that the reservoir feeding those recent eruptions, besides being extremely shallow, has a short lifetime, as mafic magma feeding the shallower system was possibly erupted soon after its injection ${ }^{26}$, 27 . The great variability in magma types and eruptive styles documented at Vesuvius therefore appears to be closely correlated with variations in depths of magma storage, pre-eruptive temperature and volatile contents. Overall, the above lines of evidence show that the shallower the reservoir, the hotter, drier and more mafic is the average composition of the erupted magma (Fig. 2).

The strong control of temperature and volatile content over eruptive regimes, and their tight relationship with pressure, imply that forecasting the next eruption at Vesuvius requires us to know the present level of magma ponding. The fact that past phonolitic to trachytic reservoirs lay at a level similar to the shallowest seismic attenuation zone revealed by seismic tomography (Fig. 2a) could mean that the seismic discontinuity reflects a present-day growing phonolitic reservoir. The subsurface levels of magma ponding may be related to the presence 
of lithological or structural discontinuities, such as the upper boundary of the carbonate basement27, which may either halt or aid the ascent of magma batches. In addition, upward migration of the level of magma ponding, whether progressive or step-like, could imply that the magma properties or the plumbing system, or both, have experienced an irreversible change over time. Melt inclusion studies17have revealed a change in the major element composition of the feeding magmas, from K-basaltic to tephritic, and this is mirrored by the evolution trends of erupted rocks18, 22, in particular during the period between the Avellino and Pollena eruptions. This may imply a difference in volatile content, and thus buoyancy, of the feeding magmas. Along the same lines, recent work has suggested the possibility of extensive carbonate ingestion of mafic magmas at Vesuvius, with massive production of CO2 which may also affect magma buoyancy29. Change in the local stress field10 following caldera formation22, 24 or gravitational spreading of the volcano onto its weak sedimentary substratum11, may also have played a part. Modelling work has shown that changes in shape and size of a volcanic edifice strongly affect eruption behaviour12. In particular, reduction of overburden and tension allows magma batches to pond at higher levels, with a consequent reduction of repose times and extent of differentiation.

Changes in pressure of magma storage similar to those observed at Vesuvius, again with the more felsic products associated with the deeper reservoirs, have been documented at Mount St Helens (160 to $300 \mathrm{MPa}$; ref. 13), albeit occurring over a shorter timescale (4 kyr). An increase of the reservoir pressure acts to reduce the flux of magma from the deep source12, assisting in protracted cooling and differentiation; such a feedback mechanism may have been operative at both Mount St Helens and Vesuvius. Although the weighted average rate of magma supply is estimated22 to have remained broadly constant over the past 10,000 yr, variations in feeding rates over three orders of magnitude, closely associated to variations in eruption styles, have been documented during the 1631-44 period27. Therefore the outstanding question is whether such changes may have happened during periods preceding important explosive events.

Our findings have several implications for hazard mitigation at Vesuvius. First, numerical models aimed at simulating the dynamics of the next eruptions at Vesuvius have so far considered the shallow reservoir to have a fixed position in the upper crust30, whereas our results show that it may have varied considerably over time. Second, models predicting the size of the next likely event are all based on the assumption that the magma feeding rates of upper reservoirs have remained broadly constant over at least the past $4 \mathrm{kyr}$. In the light of our results, the possibility that the feeding rate has fluctuated, in particular before Plinian events, should be considered. Third, it is of utmost importance that the type of fluid and/or magma stored at 8-9 km depth is properly identified. Geophysical methods cannot distinguish mafic from felsic magmas, being able to detect at best the presence of fluids encapsulated in solids. Substantial effort is needed to increase the chemical resolution of geophysical surveys.

\section{Methods Summary}

We investigated the phase equilibria of the four selected phonolites through crystallization experiments. We first melted the phonolites at 1 bar and $1,500{ }^{\circ} \mathrm{C}$ to obtain dry and crystalfree glasses, which were then ground fine. We prepared experimental charges by loading into gold capsules the powdered dry glass together with known amounts of water and CO2 (added as silver oxalate). Capsules were welded shut before annealing at high $\mathrm{P}$ and $\mathrm{T}$. Experiments were mostly done using an internally heated vessel, with $\mathrm{Ar}-\mathrm{H} 2$ mixtures as a pressurizing gas, and maintaining redox conditions between those of the nickel-nickel oxide buffer (NNO) and $1 \log$ fO2 unit above this $(\mathrm{NNO}+1)$. A few low-temperature experiments were also done in cold-seal pressure vessels, pressurized with argon. Redox conditions were continuously monitored with a semi-permeable H2 membrane placed next to the sample holder. The 
thermal gradient across the sample holder was monitored with three to four inconel-sheathed thermocouples and was always less than $2{ }^{\circ} \mathrm{C}$. Altogether, run temperatures and pressures are known to within $\pm 5{ }^{\circ} \mathrm{C}$ and $2 \mathrm{MPa}$. Most experiments consisted of running the four phonolite compositions together, exploring for each a range of $\mathrm{H} 2 \mathrm{O} / \mathrm{CO} 2$ fluid ratios. Typically an experiment consisted of annealing 20 to 30 charges simultaneously, minimizing any variations in phase assemblages and compositions that might have arisen from differences in applied P-T-fH2. Run durations varied according to temperature, between 4 and 28 days. Experiments were ended by isobaric quenching. After completion of the experiment, capsules were weighed to check for leaks, then opened. Half of the recovered run product was mounted in epoxy resin and polished for subsequent optical inspections, scanning electron microscopy and electron microprobe analyses.

\section{Full methods accompany this paper.}

\section{References}

Guidoboni, E. \& Boschi, E. Vesuvius before the 1631 eruption. Eos 87, 417-423 (2006)

Heiken, G. Will Vesuvius erupt? Three million people need to know. Science 286, 1685-1687 (1999)

Barberi, F. et al. The Somma-Vesuvius magma chamber: a petrological and volcanological approach. Bull. Volcanol. 44, 295-315 (1981)

Belkin, H. E., De Vivo, B., Roedder, E. \& Cortini, M. Fluid inclusion geobarometry from ejected Mt Somma-Vesuvius nodules. Am. Mineral. 70, 288-303 (1985)

Marianelli, P., Sbrana, A., Métrich, N. \& Cecchetti, A. The deep feeding system of Vesuvius involved in the recent violent strombolian eruptions. Geophys. Res. Lett. 32 doi:

10.1029/2004GL021667 (2005)

Fulignati, P. \& Marianelli, P. Tracing volatile exsolution within the 472 ad 'Pollena' magma chamber of Vesuvius (Italy) from melt inclusion investigation. J. Volcanol. Geotherm. Res. 161, 289-302 (2007)

Fulignati, P., Marianelli, P., Métrich, N., Santacroce, R. \& Sbrana, A. Towards a reconstruction of the magmatic feeding system of the 1944 eruption of Mt Vesuvius. J. Volcanol. Geotherm. Res. 133, 13-22 (2003)

Auger, E., Gasparini, P., Virieux, J. \& Zollo, A. Seismic evidence of an extended magmatic sill under Mt Vesuvius. Science 294, 1510-1512 (2001) |

Landi, P., Bertagnini, A. \& Rosi, M. Chemical zoning and crystallisation mechanisms in the magma chamber of the Pomici di Base plinian eruption. Contrib. Mineral. Petrol. 135, 179197 (1999)

Ventura, G., Vilardo, G. \& Bruno, P. P. The role of flank failure in modifying the shallow plumbing system of volcano: an example from Somma-Vesuvius, Italy. Geophys. Res. Lett. 26, 3681-3684 (1999) |

Borgia, A. et al. Volcanic spreading of Vesuvius, a new paradigm for interpreting its volcanic activity. Geophys. Res. Lett. 32 doi: 10.1029/2004GL022155 (2005)

Pinel, V. \& Jaupart, C. Magma chamber behavior beneath a volcanic edifice. J. Geophys. Res. 108 doi: 10.1029/2002JB001751 (2003)

Gardner, J. E., Rutherford, M., Carey, S. \& Sigurdsson, H. Experimental constraints on preeruptive water contents and changing storage prior to explosive eruptions of Mount St Helens volcano. Bull. Volcanol. 57, 1-17 (1995)

Martel, C. et al. Magma storage conditions and control of eruption regime in silicic volcanoes: experimental evidence from Mt Pelée. Earth Planet. Sci. Lett. 156, 89-99 (1998) 
Scaillet, B. \& Evans, B. W. The June 15, 1991 eruption of Mount Pinatubo. I. Phase equilibria and pre-eruption P-T-fO2-fH2O conditions of the dacite magma. J. Petrol. 40, 381-411 (1999)

Sigurdsson, H., Cornell, W. \& Carey, S. Influence of magma withdrawal on compositional gradients during the ad 79 Vesuvius eruption. Nature 345, 519-521 (1990)

Cioni, R. et al. Compositional layering and syn-eruptive mixing of a periodically refilled shallow magma chamber: the ad 79 Plinian eruption of Vesuvius. J. Petrol. 36, 739-776 (1995)

Cioni, R., Marianellia, P. \& Santacroce, R. Thermal and compositional evolution of the shallow magma chambers of Vesuvius: evidence from pyroxene phenocrysts and melt inclusions. J. Geophys. Res. 103, 18277-18294 (1998)

Civetta, L. \& Santacroce, R. Steady state magma supply in the last 3400 years of Vesuvius activity. Acta Vulcanol. 2, 147-159 (1992)

Rosi, M. \& Santacroce, R. The ad 472 Pollena eruption: volcanological and petrological data for this poorly known plinian-type event at Vesuvius. J. Volcanol. Geotherm. Res. 17, 249271 (1983)

Civetta, L., Galati, R. \& Santacroce, R. Magma mixing and convective compositional layering within the Vesuvius magma chamber. Bull. Volcanol. 53, 287-300 (1991)

Santacroce, R. (ed.) Somma-Vesuvius (CNR Quaderni de La Ricerca Scientifica, 1987)

Cioni, R. Volatile content and degassing processes in the ad 79 magma chamber at Vesuvius

(Italy). Contrib. Mineral. Petrol. 140, 40-54 (2000)

Rosi, M., Principe, C. \& Vecci, R. The 1631 Vesuvius eruption. A reconstruction based on historical and stratigraphical data. J. Volcanol. Geotherm. Res. 58, 151-182 (1993)

Rolandi, G., Barrella, A. M. \& Borrelli, A. The 1631 eruption of Vesuvius. J. Volcanol. Geotherm. Res. 58, 183-201 (1993)

Santacroce, R., Bertagnini, A., Civetta, L., Landi, P. \& Sbrana, A. Eruptive dynamics and petrogenetic processes in a very shallow magma reservoir: the 1906 eruption of Vesuvius. J. Petrol. 34, 383-425 (1993)

Scandone, R., Giacomelli, L. \& Speranza, F. F. Persistent activity and violent strombolian eruptions at Vesuvius between 1631 and 1944. J. Volcanol. Geotherm. Res. 170, 167-180 (2008)

Morgan, D. J. et al. Time scales of crystal residence and magma chamber volume from modelling of diffusion profiles in phenocrysts: Vesuvius 1944. Earth Planet. Sci. Lett. 222, 933-946 (2004)

Marziano, I., Gaillard, G. \& Pichavant, M. Limestone assimilation by basaltic magmas: an experimental re-assessment and application to Italian volcanoes. Contrib. Mineral. Petrol. doi: 10.1007/s00410-007-02677-8 (2008)

Todesco, M. et al. Pyroclastic flow hazard assessment at Vesuvius (Italy) by using numerical modelling. I. Large scale dynamics. Bull. Volcanol. 64, 155-177 (2002)

Scaillet, B., Pichavant, M., Roux, J., Humbert, G. \& Lefevre, A. Improvements of the Shaw membrane technique for measurement and control of $\mathrm{fH} 2$ at high temperatures and pressures. Am. Mineral. 77, 647-655 (1992)

Carroll, M. \& Blank, J. The solubility of H2O in phonolitic melts. Am. Mineral. 82, 549-556 (1997)

Iacono Marziano, G. \& Schmidt, B. C. \& D. o. l. f. i. D. Equilibrium and disequilibrium degassing of a phonolitic melt (Vesuvius ad 79 "White Pumice") simulated by decompression experiments. J. Volcanol. Geotherm. Res. 161, 151-164 (2007) 


\section{Acknowledgements}

We thank R. Scandone for a review, and A. Sbrana, P. Marianelli and R. Santacroce for discussions. This project was financially supported by GNV and INGV funds and by the department of the Italian Civil Defense.

Author Contributions All authors participated to the definition of the overall project strategy and to the field campaign aimed at sample selection and collection. B.S. performed the experiments, analysed the run products and produced the first draft of the paper which other authors then discussed. 
Figures
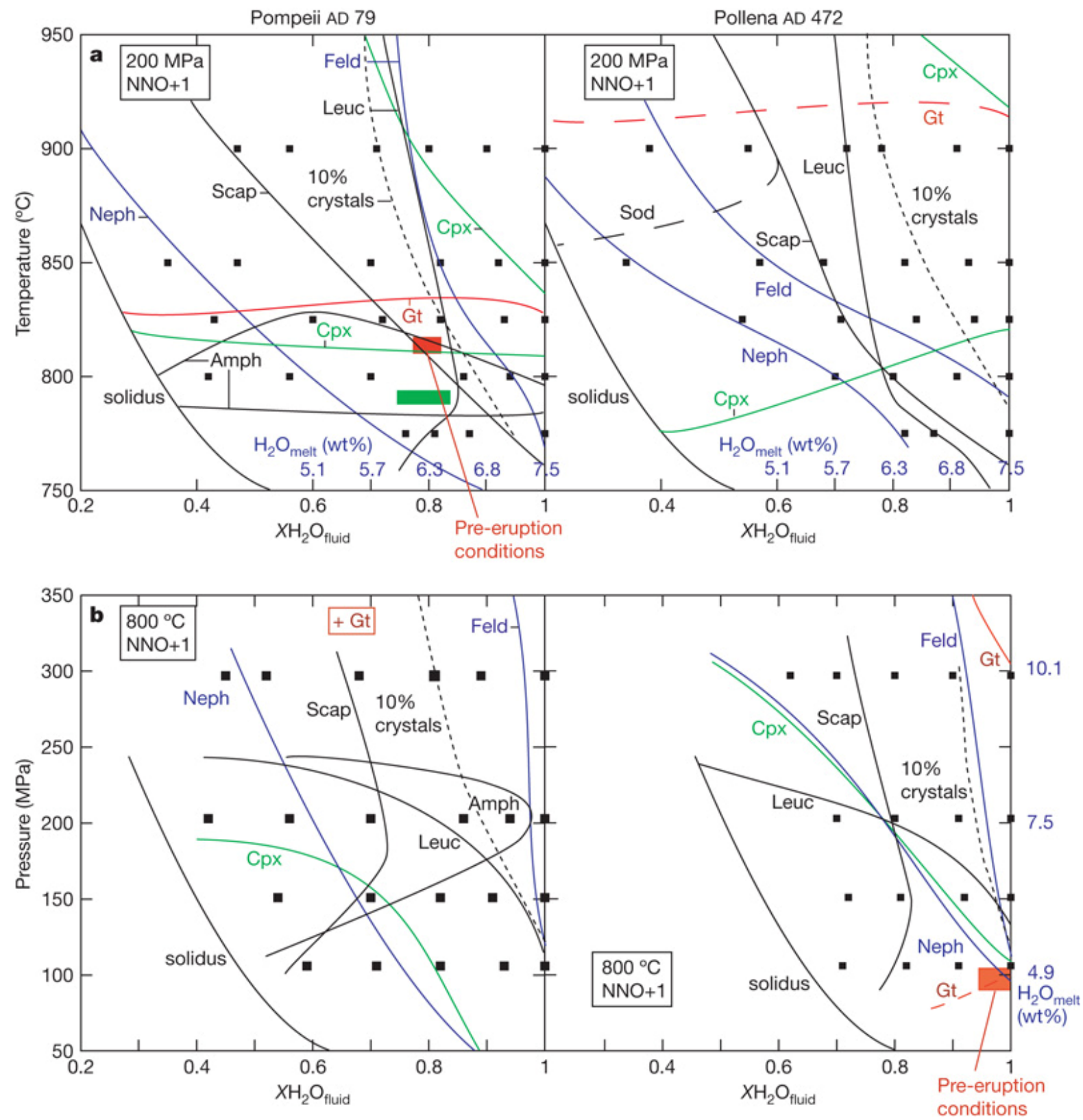

a, Isobaric/polythermal phase relationships of Pompeii and Pollena phonolites at $200 \mathrm{MPa}$. Phases lie inside their stability field. The dashed line gives the $10 \%$ modal proportion of crystals in run products. The red box shows the estimated pre-eruption conditions of temperature and $\mathrm{XH}_{2} \mathrm{O}_{\text {fluid }}$ $\left(\mathrm{XH}_{2} \mathrm{O}_{\text {fluid }}\right.$ being the mole fraction of $\mathrm{H}_{2} \mathrm{O}$ in the fluid phase), as inferred from the phenocryst assemblage of the Pompeii phonolite. The correspondence between $\mathrm{XH}_{2} \mathrm{O}_{\text {fluid }}$ and $\mathrm{H}_{2} \mathrm{O}_{\text {melt }}$ is given along the lower horizontal axis. The thick green bar is the range of $\mathrm{H}_{2} \mathrm{O}_{\text {melt }}$ obtained from the analysis of melt inclusions in sanidine phenocrysts of the Pompeii phonolite ${ }^{23}$. For Pollena, note the impossibility of co-crystallizing clinopyroxene and nepheline while maintaining crystal-poor conditions $(10 \%)$. b, Isothermal/polybaric phase relationships of Pompeii and Pollena phonolites at $80{ }^{\circ} \mathrm{C}$. The water contents at saturation are given along the vertical right axis. Leucite is not stable at pressures much higher than $200 \mathrm{MPa}$, notably under $\mathrm{H}_{2} \mathrm{O}$-rich conditions. The red box shows the estimated pre-eruption $\mathrm{T}-\mathrm{XH}_{2} \mathrm{O}$ conditions of Pollena, as inferred from the phenocryst assemblage of the Pollena phonolite. Phase abbreviations are: Feld: feldspar; Leuc: leucite; Amph: amphibole; Gt: garnet; Cpx: clinopyroxene; Neph: nepheline; Scap: scapolite; Sod: sodalite. Note that in both compositions, biotite is present in runs below $850^{\circ} \mathrm{C}$, and plagioclase occurs along with sanidine, although the latter largely predominates over the former (see Supplementary Information). Black squares represent the $\mathrm{T}-\mathrm{XH}_{2} \mathrm{O}_{\text {fluid }}$ location of individual experimental charges. 

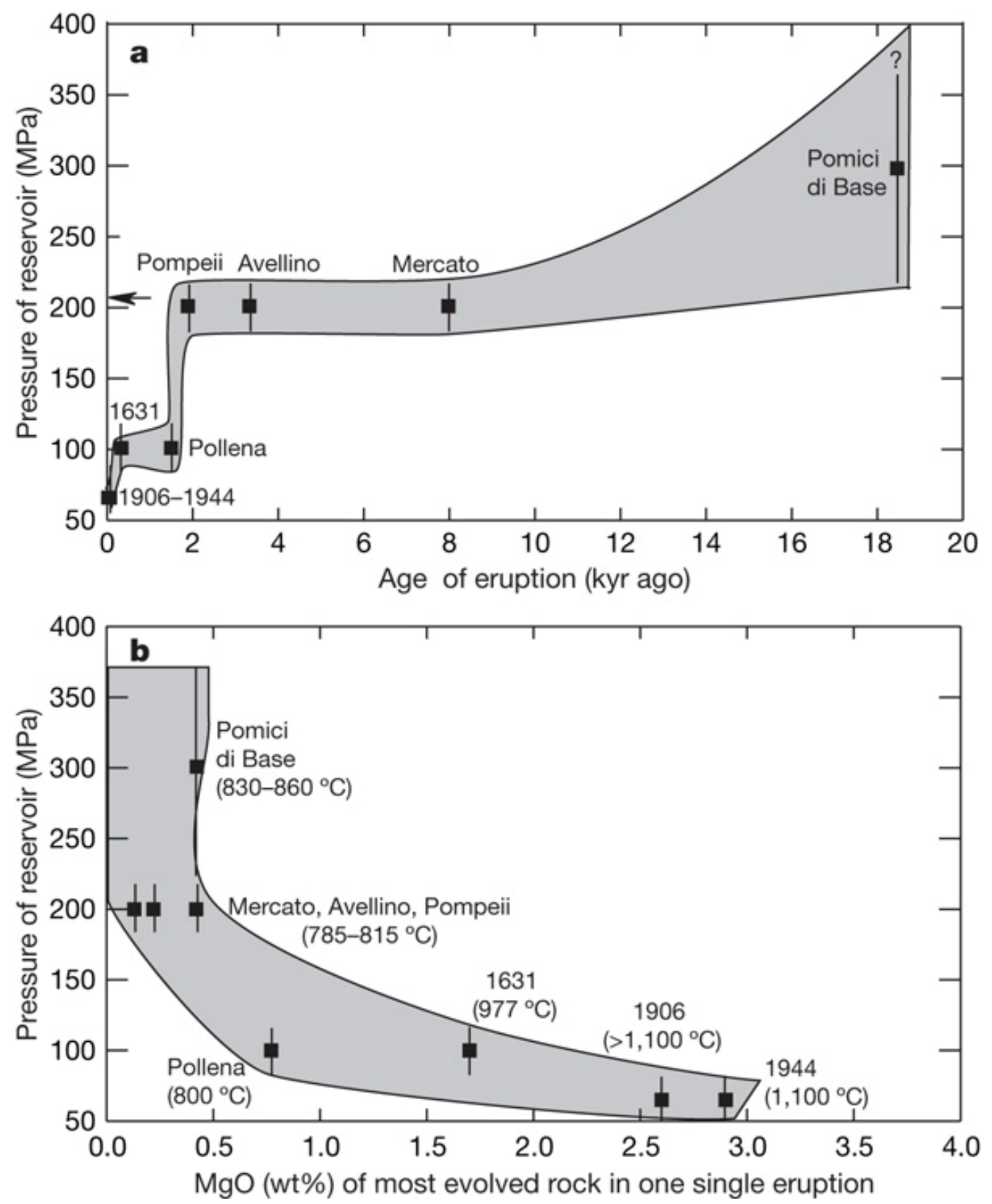

a, We show only eruptions for which the petrology of erupted products has been studied in some detail. The grey field represents the time evolution of the pressure of magma storage. The horizontal arrow on the left vertical axis represents the approximate location of shallowest level of seismic attenuation identified by tomography ${ }^{8} . b$, Variation of the extent of chemical differentiation with the pressure of magma storage (grey field). We take as a differentiation index the bulk MgO content of the rock. Because the main fractionating phase assemblage is $\mathrm{Cpx} \pm \mathrm{OI}$, the MgO content of the residual liquid always decreases with fractionation. For each eruption we have reported the most evolved rock composition belonging to the corresponding volcanic deposit. Also indicated are the corresponding temperatures of the magma, assumed to represent the topmost part of the emptied reservoir (Table 1 ). Note that, for those eruptions that produced phonolitic magma, the general decrease in temperature is also mirrored by a decrease in the abundance of felsic derivatives in the erupted products. It varies from near $100 \%$, as in the Mercato event, to a few per cent in the case of Pollena, down to $0 \%$ for all eruptions since 1631 . The error bars represent the uncertainty in the pressure of magma storage as inferred either from experiments (this work) or petrological analysis (ref. 9, 7, 18, 26). 
Table 1. Storage conditions of Vesuvius magmas over the past $20 \mathrm{kyr}$.

\begin{tabular}{|l|l|l|l|l|l|l|}
\hline Eruption & $\begin{array}{l}\text { Age } \\
\text { (kyr) }\end{array}$ & $\mathbf{P}$ (MPa) & $\mathbf{T}\left({ }^{\circ} \mathbf{C}\right)$ & $\begin{array}{l}\mathbf{H}_{2} \mathbf{O}_{\text {melt }} \\
(\mathbf{w t \%})\end{array}$ & $\mathbf{X H}_{2} \mathbf{O}_{\text {fl }}$ & $\begin{array}{l}\text { MgO } \\
\text { (wt\%) }\end{array}$ \\
\hline
\end{tabular}

Sources: P- T- $\mathrm{H}_{2} \mathrm{O}_{\text {melt }}$ conditions for Mercato, Avellino, Pompeii and Pollena events are from this work. Other data are from ref. 9 for the Pomici di Base, and refs 7,18,26 for the 1906 and 1944 eruptions. The pre-eruption temperature for the 1631 eruption was calculated using the $\mathrm{CaO}$ content of the most felsic groundmass glass ${ }^{25}$ and $\mathrm{CaO}$ geothermometry ${ }^{18}$. The pre-eruption temperature of the 1944 eruption was also calculated using the CaO content ${ }^{18}$ of groundmass glass ${ }^{7}$. For all eruptions, $\mathrm{P}-\mathrm{T}-\mathrm{H}_{2} \mathrm{O}_{\text {melt }}$ conditions correspond to the topmost part of the crustal reservoir. $\mathrm{XH}_{2} \mathrm{O}_{\mathrm{fl}}$ is the mole fraction of $\mathrm{H}_{2} \mathrm{O}$ in the coexisting fluid phase. 